\title{
Research on System Change and Innovation of Rural Financial System in China
}

\section{Li He,Wang Qianfei}

\section{Northeast Agricultural University Harbin , Heilongjiang Province 150030}

\begin{abstract}
By studying the characteristics of changes in China's rural financial system, thispaper analyzes the current lack of rural financial system, and proposes the substantive issues of supply and demand in rural financial system innovation, in order to promote the establishment of new rural financial system to adapt to rural economic development.
\end{abstract}

Keywords: Rural area, rural financial system, system change, innovation

\section{INTRODUCTION}

Shortly after the founding of New China, in order to fight the usury activities prevalent in rural to promote the stability and development of rural economy and financial, the government establishes a large number of rural credit cooperatives organization. Rural financial system change has gone through three stages as follows: Rural credit cooperatives was owned by the people's commune management phases; Foundation of agricultural bank and rural credit cooperatives became the grassroots organization of agricultural bank; Establishment of the agricultural development bank and the decoupling of cooperative and agricultural bank stage. The above historical changes of rural financial system have the following two distinct features:

1. Every rural financial system change is a mandatory top-down rather than bottom-up government-induced behavior the government conducted, but not the subject of independent behavior of the rural economy.

2. Rural financial system and rural economic system path are contrary. First, since 1979, there have been two historic reform in rural economic system, which have taken a bottom-induced changes in the way. Secondly, these two changes in the rural economic system are subject to further clarify the property relations of rural economy, but changes in the rural financial system make the relationship between ownership of rural financial institutions more blurred.

\section{Current Lack of Rural Financial System}

The existing rural financial system exposes many flaws in the actual operation of theory and practice.

2.1 The property rights status of rural financial institutions remains unclear

After credit cooperative decoupled from the agricultural bank, the status of cooperative financial institutions was made restoration, farmers can become members by shares, property was owned by all members, where property relations should be clear. The vast majority of rural credit cooperatives are not new, but several historical changes were based on rural credit cooperatives. Then, in fact the original owner's equity remains difficult to define. As a country-owned banks, agricultural bank highlights the issue of property rights, incomplete legal status in the property is subject to blur. Under the current commission system, the property rights of the state and the bank lack of real interest association, bank managers lack intrinsic motivation to chase profits, government operators lack effective supervision and incentives.

2.2 The lack of competition in the main rural financial market

At present, there are various forms of financial institutions in China's rural financial market, but they 
do not form an effective mechanism of competition between these financial organizations. As a state-owned commercial banks, Agricultural Bank has undergone major changes in market positioning, business has no difference from other state-owned commercial banks, but the perspective of competition has transformed from rural to urban, from industrial and commercial to agriculture. Various forms of private lending is a non-formal financial sector, encouragement and protection from government policy, and has a high financial transaction costs. Thus, the rural credit cooperatives has become almost the only formal financial institution in financial markets. As a cooperative financial institution, there is a clear geographical restrictions. Its operating performance also depends on excellent location. There are few good operating results in the developed regions, even if mismanaged credit cooperatives may also have a greater profit.

\subsection{The government makes disorganized management of rural financial}

Agricultural Bank was defined as a commercial bank in 1995, but still shouldered some of the policy business, there are still many administrative interventions in agricultural bank personnel, finance, business, and the intervention of local government loans is still a certain proportion, and so on. Although cooperative financial requirement is established by Congress members, the Council and the Board of Supervisors are useless. The Government continues to hold a dominant position in the management of rural credit cooperatives.

\section{Substantive Issues of Supply and Demand in Rural Financial System Innovation}

In the economic reform process, the rural financial system innovation has a huge demand for objective, which causes defects in addition to the system itself, it also includes:

(1) After economic reform, the organization and property rights structure of rural economic organization has undergone profound changes to achieve a diverse marketization. The system has been unable to make corresponding with single unstandardized synthetic of rural financial institutions.

(2) The rural industrial structure makes a major adjustment, and the proportion of secondary and tertiary industries rises, individual private enterprises have developed rapidly, and the amount of capital investment and technological content of agricultural was growing.

(3) With the increasing income of farmers, farmers are increasingly satisfied with a single savings account, from the perspective of risk diversification, farmers also want to invest in a variety of financial assets in order to obtain maximum benefits.

(4) The peasants have a strong desire to legalize and standardize private lending.

Compared with the strong demand for rural financial system innovation, the supply is obviously insufficient for two main reasons. (1) The lack of institutional innovation main supply. (2) The high cost of innovation system. Other economic entities outside the government carried the cost of rural financial system innovation, in addition to the replacement of the old and new system and the possible impact of the loss, but also including the possibility of being banned government and other interest groups and other costs.

3.1 An effective way to resolve these contradictions is financial deepening to increase innovation and supply system. Specifically, we may take the following methods.

(1) The relaxation of restrictions on market access to private financial institutions, and increase rural financial market competition and innovation in the main body.

(2) The establishment of incentives, from the regime to ensure that economic agents should get a reward or benefit with minimum financial innovation. The economy subject to the expected return is greater than the expected cost of system innovation.

(3) Put emphasis and limits the "free rider" 
phenomenon. In the system and economics literature, the "free rider" is interpreted as enjoying the innovations of others, compared with the innovator, "free riders" is that benefits the same as, the cost is almost zero. So if the "free rider" phenomenon does not overcome, the economic body will be very difficult to be innovative and initiative.

\section{Innovative Ways in Rural Financial System}

(1)The effect of the introduction of the new system depends mainly on two factors. The first is that government demand for institutional innovation judgment is correct. The second is whether the Government's interest is consistent with other economic stakeholders. Only this both is yes, the new financial system is effective, otherwise it will be inefficient or ineffective. During the rural credit cooperatives, as the people's communes, rural credit cooperatives funds were misappropriated commune or production team for a lot of business activities are close to paralysis. Again, the decision-makers seems more conducive to cooperative financial institutions in the form of government to achieve objectives of the reform of state-owned commercial banks, so they are adopted across the board in the country, although in many places its efficiency is not ideal.

(2) In this way, due to that the rural financial system innovation is initiated and imposed by the government, so the form has a faster diffusion effect, almost overnight to complete the replacement of old and new system. However, the actual rate of diffusion of innovation depends on whether other relevant interest groups welcome this system.

(3) Due to the long-term implementation of Supply System in innovative ways, the rural financial system of the relevant interest groups have been accustomed to the institutional arrangements of government, and the original path of institutional change has a strong dependence. Such as: As the grass-roots organization of Agricultural Bank, though RCC still has some problems in theory and practice, it is not against the various interest groups to maintain the status. RCC managers prefer that RCC becomes a "government-run" or "state run", the democratic management of rural credit cooperatives have been extremely strange to the peasants, and agricultural banks are reluctant that RCC separates from their jurisdiction, and so on. In fact, in human relations, the business and other aspects of RCC still has a greater dependence on the agricultural bank.

To solve these problems, the only way is to change the system innovation, the government supply-led approach can induce a gradual transition to a demand-type approach, namely to encourage peasants and rural financial organization system innovation spontaneously, then, the government makes ratify and promotion in order that the countryside innovation is consistent with the requirements of the internal development of the financial system, to better promote rural economic and financial development.

\section{Property Rights Innovation of Rural financial System}

Efficient property rights should be competitive, the current financial organizations form a single cooperative rural property and ambiguous property relations, neither meet the needs of rural property structure and industrial structure changes, also due to lack of competition and inefficiency. Therefore, the government should capitalize on the trend to gradually establish a diversified rural economic to adapt to the internal needs of rural financial institutions in the form of property right structure.

First, under the principle of adhering to the rural cooperative financial institutions in the form of fundamental rights, we should redefine the property rights of existing rural credit cooperatives, and in accordance with the actual situation of regional economic and financial development, RCCs will be built into cooperative Bank as a legal association, the number of rural credit cooperatives be merged into a 
corporation as a single credit cooperatives. Government give support to cooperative financial organizations in tax policy, but without the direct intervention of its personnel, finance, and other business activities.

Secondly, in the areas of developed private economy with good financial fundamentals, we can form the private commercial banks in order to regulate the increasingly active private financial activities. Private commercial banks with registered capital have a high starting point, the property can take the form of joint-stock or stock cooperative system, management is fully in accordance with market principles.

Finally, recently, the government should make a certain percentage that the Agricultural Bank should invest in farming funds to ensure that rural infrastructure and agricultural technology required relatively large capital needs. The basis of the state-owned commercial banks, joint-stock reform on the part of rural branches of the Agricultural Bank into an independent legal entity after the sale to the private sector.

\section{CONCLUSIONS}

It is worth emphasizing innovation and ownership of structure adjustment. Rural financial institutions must be market-related spontaneous behavior of economic agents and voluntary action. The government only provides market access and exiting mechanisms. While reducing financial volatility innovation ownership structure adjustment may cause, it is necessary to formulate relevant laws and regulations.

\section{References}

[1] Ping X. The Debate on the Reform of China's Rural Credit Cooperatives System[J]. Journal of Finance, 2001.

[2] Boyreau-Debray G, Wei S J. Pitfalls of a state-dominated financial system: The case of China[R]. National Bureau of Economic Research, 2005.

[3] Jie Z. Financial Difficulties and Financing Sequences of Private Economy[J]. Economic Research Journal, 2000, 4: 000.

[4] Liu C, Wang F, et al. Robust Ho Control for Satellite Attitude Control System with Uncertainties and Additive Perturbation[J]. International Journal of Science, 2014, 1(2): 1-9.

[5] Whiting S H. Power and wealth in rural China: the political economy of institutional change[M]. Cambridge University Press, 2006.

[6] Xibao L. A Case Study on the Changes in the Innovation Capability of China's Regions: a Concept Based on the Innovation System[J]. Management World, 2007, 12: 18-30.

[7] Shi K, Sun Z, Liu C. Design of Microsatellite Attitude Control with Multiplicative Perturbation of Controller $[\mathrm{C}] / /$ Control and Decision Conference (2015 CCDC), The 27th Chinese. IEEE, 2015. 